\title{
Rafat Swakon
}

https://orcid.org/0000-0002-1023-6987

Wydział Historyczny Uniwersytetu Jagiellońskiego

\section{Józefa Kazimierza Plebańskiego krytyka tzw. krakowskiej szkoły historycznej}

Zarys treści: $\mathrm{W}$ artykule przedstawiono dzieje krytyki, jakiej warszawski historyk Józef Kazimierz Plebański, uczeń Leopolda Rankego i zwolennik historyzmu, poddał dzieła reprezentantów tzw. krakowskiej szkoły historycznej. Krytyka ta koncentrowała się na zasadniczym, zdaniem Plebańskiego, metodologicznym błędzie krakowskich uczonych, jakim był prezentyzm w interpretowaniu dziejów Polski. Z tej perspektywy przybliżone będą Plebańskiego omówienia prac Józefa Szujskiego, Waleriana Kalinki, Michała Bobrzyńskiego, Wincentego Zakrzewskiego (którego warszawski uczony uznawał za przedstawiciela szkoły krakowskiej) oraz jego stosunek do samego zjawiska „nowej szkoły historycznej”.

The content outline: This article deals with the criticism to which a Warsaw historian, Józef Kazimierz Plebański, subjected works by representatives of the so-called Kraków school of history. Plebański, who studied under Ranke and shared Ranke's historicist outlook, concentrated his criticism on the present-mindedness of the Kraków scholars' interpretation of Polish history, considering it to be the key methodological error they committed. Following this perspective, the article shows how Plebański perceived the phenomenon known as the 'new historical school' and how he viewed works by such scholars as J. Szujski, W. Kalinka, M. Bobrzyński and W. Zakrzewski (whom Plebański also included among members of the Kraków school of history).

Słowa kluczowe: Józef Kazimierz Plebański, krakowska szkoła historyczna, historyzm, krytyka

Keywords: Józef Kazimierz Plebański, the Kraków school of history, historicism, criticism

Recepcja dzieł i poglądów krakowskiej szkoły historycznej to temat niejednokrotnie podejmowany przez historyków historiografii ${ }^{1}$. Obserwowano reakcje

${ }^{1}$ Zob. przede wszystkim: B. Krzemieńska-Surowiecka, Polemika wokół „Dziejów Polski w zarysie” Michała Bobrzyńskiego (w latach 1879-1890), „Zeszyty Naukowe Uniwersytetu Łódzkiego. Seria 1. Nauki Humanistyczno-Społeczne" 1956, nr 4, s. 107-128; A.F. Grabski, Jeszcze o sporach wokót „Dziejów Polski w zarysie”, w: tenże, Perspektywy przeszłości. Studia i szkice historiograficzne, Lublin 1983, s. 279-320; tenże, „Podpalacze” przeciw „lidze brandmajstrów”, w: tamże, s. 342-412; H. Słoczyński, Z dziejów czarnej legendy krakowskiej historiografii konserwatywnej. Józef Szujski 
współczesnych Józefa Szujskiego i Michała Bobrzyńskiego na ich dziejopisarskie wypowiedzi, a także ich odbiór w XX i XXI w. ${ }^{2}$ Jak jednak dowodzi tego chociażby artykuł Jolanty Kolbuszewskiej o stosunku Tadeusza Korzona do szkoły krakowskiej, problem dziewiętnastowiecznych polemik z podwawelskim kierunkiem wciąż daleki jest od wyczerpania ${ }^{3}$. W niniejszym artykule chciałbym przyjrzeć się jednemu z mniej rozpoznanych wątków owych polemik, za jaki pomimo istniejącej literatury należy uznać ocenę dorobku badawczego „nowej szkoły historycznej” przez Józefa Kazimierza Plebańskiego, warszawskiego historyka niezwiązanego ze szkołą warszawską, którego Michał Bobrzyński określił mianem jednego $\mathrm{z}$ „najzdolniejszych, chociaż nie najpłodniejszych naszych historycznych pisarzów"4.

Józef Kazimierz Plebański (1831-1897) zasłynął przede wszystkim jako badacz siedemnastowiecznej Rzeczypospolitej, skupiając swą uwagę na panowaniu Jana Kazimierza Wazy oraz kwestiach ustrojowych. Poświęcił im zarówno swój doktorat, jak i książkę Jan Kazimierz Waza - Maria Ludwika Gonzaga. Dwa obrazy historyczne (Warszawa 1862). Przygotowywał również obszerną pracę pt. Historia sejmów polskich, zapowiadaną w warszawskiej prasie, która jednak nigdy nie ujrzała światła dziennego. Interesował się też dziejami historiografii oraz szeroko pojętą metodologią i filozofią historii (prace takie jak O historycznem znaczeniu Juliusza Cezara, wykłady pt. Encyklopedia i metodologia nauk historycznych czy też Historiografia polska), a także geografią i filologią (bardzo obszerne hasła w encyklopedii Orgelbranda) oraz nauczaniem (m.in. praca O pedagogicznem znaczeniu nauk klassycznych). Po studiach we Wrocławiu i Berlinie uczył historii w Gimnazjum św. Marii Magdaleny w Poznaniu (tam jego uczniem był Ksawery Liske). W latach 1862-1869 prowadził wykłady w Szkole Głównej Warszawskiej, a od 1880 do $1890 \mathrm{r}$. był redaktorem naczelnym „Biblioteki Warszawskiej”. W latach 1881-1890 współredagował również Encyklopedyję wychowawczą. Mieszkał w Izdebnie pod Warszawą, gdzie zmarł w 1897 r.

w opiniach wspótczesnych i potomnych, „Kwartalnik Historyczny” 102, 1995, nr 3/4, s 209-244; A. Wierzbicki, Wokót „czarnej legendy” historiografii krakowskich konserwatystów, „Kwartalnik Historyczny" 104, 1997, nr 2, s. 63-87; A. Wardzińska, Dwa spojrzenia na historię Polski. Polemika demokratów lwowskich Henryka Schmitta i Ludwika Wolskiego z przedstawicielem krakowskiej „nowej szkoły historycznej” Józefem Szujskim w latach 70. XIX wieku, „Klio Polska. Studia i Materiały z Dziejów Historiografii Polskiej” 9, 2017, s. 7-31; J. Kolbuszewska, Spór o wizję dziejów, metodę, wartości - Tadeusz Korzon wobec „krakowskiej szkoły historycznej”, w: Krakowska szkoła historyczna a Polskie Towarzystwo Historyczne. Studia historiograficzne, red. P. Biliński, P. Plichta, Kraków 2017, s. 241-254.

${ }^{2}$ Ostatnio np. Z. Romek, Wizja dziejów Polski według krakowskiej szkoły historycznej a podręczniki szkolne III RP, w: Krakowska szkoła historyczna a Polskie Towarzystwo Historyczne..., s. 165-182; R. Stobiecki, O pewnej wspólczesnej, brawurowej próbie odczytania dziedzictwa krakowskiej szkoły historycznej, w: tamże, s. 183-191.

${ }^{3}$ J. Kolbuszewska, Spór o wizję..., s. 241-254.

${ }^{4}$ M. Bobrzyński, Dzieje Polski $w$ zarysie, t. 1, wyd. 2, Warszawa-Kraków 1880, cyt. za: A.F. Grabski, Jeszcze o sporach..., s. 299-300. 
Ważną część intelektualnej spuścizny Plebańskiego stanowią recenzje i polemiki $\mathrm{z}$ innymi historykami. W dyskusjach prowadzonych przez uczonych widział jedną z dróg rozwoju nauki. Jak sam zaznaczał, nauki winny wieść ze sobą „chlubny spór", stanowiący rękojmię ich postępu ${ }^{5}$. Jako historyk znakomicie wykształcony na niemieckich uniwersytetach, gdzie terminował m.in. u Leopolda von Ranke, żywo zainteresowany rozwojem swej własnej nauki, nie mógł pozostać obojętny na jeden z najważniejszych historiograficznych głosów epoki w Polsce, jakim stała się twórczość tzw. krakowskiej szkoły historycznej6.

Sprawa stosunku Plebańskiego do krakowskich historyków jest trudna do jednoznacznego określenia. $\mathrm{W}$ dotychczas poświęconych mu opracowaniach wskazywano na jego duchowe pokrewieństwo z Józefem Szujskim oraz polemikę z Michałem Bobrzyńskim . Jerzy Maternicki stwierdził nawet, że „błędem byłoby jednak sądzić na tej podstawie [polemiki z Bobrzyńskim - R.S.], że Plebański był stanowczym przeciwnikiem tzw. szkoły krakowskiej" ${ }^{8}$. Nie zwrócono dotąd jednak należytej uwagi, że Plebański bardzo ostro oceniał zarówno dorobek autora Historyi polskiej, jak i prace pozostałych przedstawicieli podwawelskiego kierunku. Ale również na tej podstawie nie można zaliczyć Plebańskiego do jego zdecydowanych antagonistów. Jak postaram się wykazać, obecna w jego krytyce ambiwalencja nie miała bowiem wymiaru personalnego, leczy była następstwem zróżnicowanego stosunku do kreowanego przez historyków krakowskich obrazu dziejów Polski, z którym zasadniczo się zgadzał, i do stosowanej przez nich metodologii, w której - jako wierny uczeń Rankego - dostrzegał fundamentalnie sprzeczny z zasadą historyzmu prezentyzm ${ }^{9}$. Był bowiem przekonany, że dzieje

${ }^{5}$ J.K. Plebański, O historycznem znaczeniu Juliusza Cezara, cz. 1, „Biblioteka Warszawska” 2, 1865, s. 172.

${ }^{6}$ O studiach Plebańskiego zob. R. Ergetowski, Studia J.K. Plebańskiego i pierwsze lata jego nauczycielskiej pracy, w: tenże, Silesiaca. Biblioteki, uczeni, studenci, wybór i wstęp E. Libura, Wrocław 2005, s. 71-129.

7 J. Maternicki, Warszawskie środowisko historyczne 1832-1869, Warszawa 1970, s. 230, $254-$ -258; A.F. Grabski, Jeszcze o sporach..., s. 299-305. Z. Libiszowska wskazywała na polemikę Plebańskiego z krakowską szkołą, jednakże - na co wskazał J. Maternicki w przywołanej wyżej pracy - jej interpretacja sądów Plebańskiego zdaje się nie do końca odpowiadać jego wypowiedziom; Z. Libiszowska, Józef Kazimierz Plebański (1831-1896), „Zeszyty Naukowe Uniwersytetu Łódzkiego. Seria 1. Nauki Humanistyczno-Społeczne" 1964, nr 4, s. 101.

${ }^{8}$ J. Maternicki, Warszawskie środowisko historyczne..., s. 258.

${ }^{9}$ Nie znaczy to jednak, że historycy szkoły krakowskiej nie reprezentowali historyzmu. Jakkolwiek wciąż nie ma pracy odnoszącej dorobek badawczy Szujskiego, Smolki itd. do tego nurtu, jednakże w literaturze przedmiotu można odnaleźć sugestie mówiące o historyzmie krakowskiej szkoły; zob. K. Zamorski, Historyzm i narodziny krakowskiej szkoły historycznej, w: Józef Szujski 1835-1883. Materiały z posiedzenia naukowego $w$ dniu 25 listopada 2013 roku, red. W. Lohman, Kraków 2015, s. 51-59; tenże, Krakowska szkoła historyczna a zagadnienie periodyzacji dziejów, w: Krakowska szkoła historyczna a Polskie Towarzystwo Historyczne..., s. 13-24; A.F. Grabski pisał o Smolce jako historyku stojącym bardzo blisko historyzmu; tenże, Z zagadnień stosunków polsko-niemieckich $w$ zakresie historiografii drugiej połowy XX w. [sic!, powinno być: XIX w.], „Kwartalnik 
ludzkości to nieustanna przemiana, a pojęcia adekwatne dla jednej epoki nie będą opowiadać prawdzie epoki następnej ${ }^{10}$. Pod tym względem jego krytyka historyków szkoły krakowskiej - sformułowana w recenzjach ich dokonań oraz na marginesie prac własnych - pozostaje niezwykle konsekwentna.

Pierwsza wzmianka Plebańskiego o Józefie Szujskim, na jaką udało mi się natrafić, znajduje się na marginesie jednej z kart drugiej redakcji rozprawy $O$ zadaniu dziejopisarstwa polskiego. Wersja ta powstała najpewniej w 1857 r., jej marginesy zapełniał jednak Plebański jeszcze na początku lat 60. XIX w. Wspomniane marginalium brzmi: „Józef Szujski, zdolny młody pisarz dramatyczny, wprowadził nieszczęśliwy do dziejów podział na doby, które rozpadają się na okresy, a okresy na akty. Ta widoczna przewaga żywiołu dramatycznego albo raczej scenicznego nie odpowiada prawdzie ścisłej nauki" 11 . Odnosi się zaś do periodyzacji ojczystej historii zaproponowanej przez Szujskiego w Dziejach Polski (t. 1-4, 1862-1864, marginalium dot. t. 1) - dziele powstałym de facto jeszcze przed ukształtowaniem się wspólnoty uczonych określonej później mianem krakowskiej szkoły historycznej ${ }^{12}$.

Plebański poddał ostrej krytyce Dzieje Polski Szujskiego jeszcze raz w 1864 r., w wykładzie pt. Historiografia polska - tym razem tę ich część, gdzie ich autor ocenia dotychczasowy dorobek polskich historyków. Tak ową ocenę podsumował warszawski dziejopis: Szujski „popisał tymczasem najoczywistsze i najlekkomyślniejsze fałsze!"13. Plebański podkreślił talent poetycki przyszłego wykładowcy uniwersyteckiego, odmawiając mu za to umiejętności niezbędnych do prowadzenia badań naukowych. Zarzucając mu nieuczciwą krytykę swych poprzedników w profesji, porównał nawet wywody Szujskiego do facecji „popsutego dzieciaka”,

Historii Nauki i Techniki” 29, 1984, nr 2, s. 336 (natomiast nie uznał za jego reprezentantów Kalinki, Szujskiego i Bobrzyńskiego).

10 Zob. np. Biblioteka Publiczna m.st. Warszawy, akc. 102, J.K. Plebański, Historiografia polska, 1864 r., k. 36r-38r; J.K. Plebański, Demokracja w ustroju starożytnych państw greckich, „Kłosy” 1887, nr 1173, s. 405; tenże, O historycznem znaczeniu..., cz. 1, s. 458. O poglądach Plebańskiego oraz o jego stosunku do historyzmu zob. A.F. Grabski, Historiografia polska wobec Leopolda von Ranke, „Przegląd Zachodni” 1987, nr 5-6, s. 169; tenże, Z zagadnień stosunków polsko-niemieckich..., s. 327-328, 336; tenże, Spór o prawa dziejowe. Kontrowersje wokót Henry'ego Thomasa Buckle'a w Polsce w dobie pozytywizmu, Lublin 2002, s. 239-241; J. Kolbuszewska, Mutacja modernistyczna w historiografii polskiej (przełom XIX i XX w.), Łódź 2005, s. 68, 73; R. Swakoń, Wizja świata i człowieka Józefa Kazimierza Plebańskiego (1831-1897), „Historyka. Studia Metodologiczne" 48, 2018, s. 373-393; tenże, Ideał nauki Józefa Kazimierza Plebańskiego (1831-1897), „Historyka. Studia Metodologiczne” 49, 2019, s. 239-262.

11 Biblioteka Publiczna m.st. Warszawy, akc. 102, J.K. Plebański, O zadaniu dziejopisarstwa polskiego, 1857 r., k. 119r.

${ }_{12}$ Zob. np. J. Maternicki, Zmierzch szkoły krakowskiej i opozycja historyków warszawskich, w: tenże, Kultura historyczna dawna i współczesna. Studia i szkice, Warszawa 1979, s. 181; tenże, Historia i życie narodu. Poglądy i postawy historyków polskich XIX i XX w., Rzeszów 2009, s. 137.

${ }_{13}$ Biblioteka Publiczna m.st. Warszawy, akc. 102, J.K. Plebański, Historiografia polska, 1864 r., k. $52 \mathrm{v}$. 
który się „w szkole ani myśleć ani pracy bliźńego szanować nie nauczy”” ${ }^{14}$. Szujski został ponadto oskarżony o brak wyobrażenia badanego przedmiotu, nierozróżnianie między badaniami starożytniczymi a historycznymi oraz o to, że za cel postawił sobie jedynie opowiadanie historii - dostarczanie literackiej rozrywki, nie zaś naukę - historii badanie ${ }^{15}$.

Zarzuty Plebańskiego można więc ująć, jak sądzę, tak - Szujski popełnił jeden z największych grzechów przeciwko historii, wprowadzając do niej swój własny porządek. Dopuścił się anachronizmu, a także intelektualnej nieuczciwości w ocenie swych poprzedników oraz wykazał braki w wykształceniu i przygotowaniu do prowadzenia badań. Szujski nie był w oczach Plebańskiego naukowcem, lecz raczej literatem. Według Plebańskiego bowiem „historia jest nauką, nie opowieścią”16. Historii nie można sprowadzić do retoryki, a „historyka nigdy nie zastąpi żaden retor" ${ }^{\prime 1}$. Historia nie jest też przedmiotem fantazji. Musi przedstawiać prawdę, opartą na poważnych badaniach naukowych. Historii nie powinni pisać poeci, lecz odpowiednio do tego przygotowani uczeni. Badanie historiograficzne wymaga innego typu wyobraźni niż poetycka czy też sceniczna, dowolnie posługująca się materiałem historycznym w celu osiągnięcia pożądanego efektu literackiego bądź emocjonalnego.

Podobne zarzuty i wątpliwości pojawiły się w opublikowanym anonimowo w 1883 r. w t. 1 „Biblioteki Warszawskiej” nekrologu Szujskiego. Autor - w którym trzeba, jak sądzę, widzieć samego redaktora (Plebański kierował „Biblioteką” w latach $1880-1890)^{18}-\mathrm{w}$ już mniej kategorycznym tonie stwierdzał, że Szujski nie kształcił się systematycznie na historyka. Dziejopis ten „nie przechodził szkoły historycznej, w dydaktycznem tego słowa znaczeniu"19, jego szkołą był gorący patriotyzm, a podstawą jego historiograficznej spuścizny - poetycka wyobraźnia. Mimo to rozwinął się tak, że jego Historya polska stoi naukowo znacznie wyżej od jego Dziejów Polski ${ }^{20}$. W nekrologu znajduje się jeszcze jedno ważne stwierdzenie. Najnowsze badania nad ojczystymi dziejami „przybrały w ostatnich latach

14 Tamże, k. 53r.

15 Tamże, k. 52v-53v.

16 Tamże, k. 53v.

17 Tamże, k. 26r.

18 Wskazuje na to podobieństwo krytyki Szujskiego, jaką dał Plebański niecałe 20 lat wcześniej, a także podobieństwo stylu do innych tekstów Plebańskiego. O publikacjach „Biblioteki Warszawskiej” więcej zob. J.R. Błachnio, „Biblioteka Warszawska”: forum polskiej filozofii w latach 1841-1915, Bydgoszcz 1999; J. Wnęk, Akademia Umiejętności na kartach „Biblioteki Warszawskiej” w latach 1872-1914, „Rocznik Biblioteki Naukowej PAU i PAN w Krakowie” 52, 2007, s. 355-379.

19 [J.K. Plebański], [Nekrolog Józefa Szujskiego], „Biblioteka Warszawska” 1883, t. 1, s. 471.

20 Historya polska została dość pozytywnie oceniona na łamach „Biblioteki” przez Franciszka Krupińskiego w t. 4 z 1880 r., s. 296-313. Podobnie (anonimowe) dobre oceny innych prac Szujskiego można znaleźć w t. 4 z 1881 i t. 2 z 1882 r., odpowiednio s. 480-481 (o Opowiadaniach i roztrzasaniach historycznych) i 304-306 (O Polakach i Rusinach w Galicji). 
nowy kierunek przeważnie pod wpływem zapału politycznego ś. p. J. Szujskiego, uczonego obywatela, bolejącego nad dolą kraju i społeczeństwa"21. Szujski - tutaj „uczony obywatel”, nie zaś profesjonalny historyk - zdaniem redakcji „Biblioteki Warszawskiej" miał zapoczątkować, dzięki swej politycznej myśli, nowy kierunek interpretacji rodzimych dziejów w naszej historiografii ${ }^{22}$.

Stosunek Plebańskiego do Szujskiego uległ chyba delikatnej przemianie pod koniec lat 80. Jeszcze w $1887 \mathrm{r}$. w recenzji książki Wiktora Czajewskiego - to w ogóle jeden z najostrzejszych tekstów recenzyjnych redaktora „Biblioteki Warszawskiej” - pisał, że książki Szujskiego i Bobrzyńskiego „go słusznie nie zadawalniały”23. Tymczasem w 1891 r., w recenzji książki Władysława Abrahama napisał, że na szczęście historyk ten nie idzie pod rękę „osobnej, oryginalnej "nowej szkoły«” (szkoły krakowskiej; do tego tekstu powrócę w dalszej części artykułu), lecz raczej kroczy drogą uczonych niemieckich, ale także Helcla, Kalinki i... Szujskiego właśnie. Być może z perspektywy czasu dostrzegł Plebański w pisarstwie historycznym Szujskiego wartości, które nie były dlań widoczne wcześniej lub też zdał sobie również sprawę z pewnego pokrewieństwa jego własnego, prowidencjalistycznego myślenia o historii $\mathrm{z}$ wizją Szujskiego. Być może uznał też dzieła następców Szujskiego za nieporównanie słabsze od jego Historyi polskiej.

Także twórczość innych przedstawicieli krakowskiej szkoły historycznej wzbudzała sprzeciw Plebańskiego, któremu konsekwentnie dawał wyraz przez całe lata 80. XIX w. Poddał krytyce dzieła Michała Bobrzyńskiego, Waleriana Kalinki, Wincentego Zakrzewskiego, a także samo zjawisko „tzw. nowszej szkoły historycznej"24. Warto zauważyć nieobecność w tym gronie Stanisława Smolki, którego, jak się okaże, Plebański raczej przeciwstawiał reszcie wymienionych historyków, niż dostrzegał jego z nimi pokrewieństwo.

Główny zarzut Plebańskiego pod adresem wymienionych wyżej historyków brzmiał zaś tak: nieustannie oceniają oni przeszłość z perspektywy dzisiejszych teorii politycznych. Jest to jeden $\mathrm{z}$ największych grzechów przeciwko metodzie historycznej, a w konsekwencji - przeciwko prawdzie. Jest to ten sam grzech,

${ }^{21}$ [J.K. Plebański], [Nekrolog Józefa Szujskiego]..., s. 471.

22 Trzeba tu zauważyć, że mimo raczej niechętnego stosunku Plebańskiego do Szujskiego, zdecydował się on opublikować szkic biograficzny poświęcony autorowi Dziejów Polski pióra Michała Chylińskiego w kolejnym, drugim tomie „Biblioteki” za rok 1883, s. 41-57. Chyliński przedstawił twórczość i działalność Szujskiego w jasnych barwach. Uznał nawet, że Szujski, Kalinka, Bobrzyński, Smolka, Lewicki, Kubala, Liske, Piekosiński, Zakrzewski i inni współcześni historycy tworzą w naszej historiografii nową szkołę, niepatrzącą na dzieje a priori, lecz dążącą do prawdy ponad politycznymi podziałami (s. 51-52). Niewątpliwie Plebański w żadnym razie nie podpisałby się osobiście pod takim stwierdzeniem.

${ }^{23}$ J.K. Plebański, rec.: Wiktor Czajewski: „Rys dziejów naszych”. Polska za Piastów, z mapkq Szlązku. Warszawa 1887, str. 139, „Biblioteka Warszawska” 1887, t. 1, s. 271.

${ }^{24}$ Określenie Plebańskiego; tenże, Krytyka historyczna w szkole wychowawczej, cz. 1, „Przegląd Literacki. Dodatek do »Kraju«" 1888, nr 14, s. 5. 
który - w nieco inny sposób - popełnił Józef Szujski 20 lat wcześniej: przenoszenia na przeszłość kategorii jej obcych. Przeszłość należy rozumieć. Jak pisał Plebański w 1880 r. w księdze jubileuszowej poświęconej Kraszewskiemu, historia kształci potomnych „przez to, że roztaczając przed nami wierny obraz czynów dokonanych, daje nam możność zrozumienia uzasadnionych dążeń i pragnień naszego wieku. Znamieniem tedy historycznego poglądu na przeszłość powinna być poważna i wszechstronna analiza idei, władnących naszą epoką w ich organicznym rozwoju" 25 . Historyk bada idee, które w danym momencie dziejów oddziałują na określone dziejowe podmioty - i które w efekcie przynoszą zmianę. Inny stosunek do przeszłości mają zaś politycy: „o ile historyk śledzi prawideł [sic!] organicznego rozwoju faktów, o tyle polityk skłonny jest do karcenia przeszłości za to, że nie postępowała podług teoryi dzisiejszych fakcyi politycznych, że nie służyła politycznym interesom chwili, że nie była powolnem narzędziem dla politycznych widoków dzisiejszych namiętności i dążności państwowych"26. Polityk ocenia przeszłość z perspektywy swych własnych przekonań politycznych. $\mathrm{W}$ ten sposób Plebański nakreślił różnicę między prawdziwymi historykami, piszącymi prace naukowe, a politykami, którzy mogą co najwyżej tworzyć publicystykę historyczną. Historyk miłuje prawdę, pragnie zrozumieć rzeczywistość w jej dynamice i rozwoju, polityk służy zaś swojemu partykularnemu interesowi, oddaje pokłon swoim własnym poglądów i pragnie kreować rzeczywistość. Historyk bada przeszłość, szuka w niej genezy swej współczesności. Polityk szuka w niej potwierdzenia swej własnej politycznej wizji, a nie znajdując go, oskarża przeszłość, że nie postępowała zgodnie z jego doktryną.

W tej samej księdze poświęconej Kraszewskiemu Plebański zaznaczył, że nawet uczeni profesorowie potrafią zbytnio ufać swej wiedzy na tematy społeczne i polityczne, którą starają się wykorzystać przy badaniu przeszłości, jednocześnie lekceważąc dorobek innych historyków. W ten sposób pozbawiają się możliwości sprawiedliwego oceniania przeszłości. Ich poglądy nazywa Plebański „mamidłami historycznej spekulacyi”27. Jednym z tak zadufanych uczonych jest jego zdaniem Michał Bobrzyński, który uznaje wręcz swe Dzieje Polski w zarysie za dzieło założycielskie nowej szkoły historycznej ${ }^{28}$. Tymczasem jego propozycje metodologiczne zdaniem warszawskiego badacza są już od dawna nauce znane. Plebański, na co zwrócił uwagę Andrzej Feliks Grabski, poddał krytyce przekonanie Bobrzyńskiego,

${ }_{25}$ Tenże, O pamiętnikach historycznych wydanych przez J.I. Kraszewskiego, w: Książa jubileuszowa dla uczczenia pięćdziesięcioletniej działalności literackiej J.I. Kraszewskiego, Warszawa 1880, s. 463.

26 Tamże.

27 Tamże, s. 481.

28 Warto tu jeszcze zauważyć, o czym była mowa wyżej, że kilka lat później to Szujski zostanie uznany przez redakcję „Biblioteki Warszawskiej” za właściwego twórcę (czy też renowatora, o czym dalej) politycznego kierunku w badaniach polskich dziejów. 
że historia jest jedynie przyłożeniem teorii społecznych i politycznych do materii dziejów. Zdaniem redaktora „Biblioteki Warszawskiej” winno być odwrotnie: „historya polityce powinna dostarczać światła i szacunku dla wolności i dla tych zasad moralnych, bez których nie ma prawdziwego postępu"29.

Swoje zarzuty szerzej rozwinął Plebański w liście do Bobrzyńskiego. Został on już dogłębnie zanalizowany przez Andrzeja Feliksa Grabskiego, nie ma więc potrzeby powtarzać w tym miejscu jego ustalen ${ }^{30}$. Warszawski historyk w zasadzie powtórzył swe argumenty przedstawione w Książce jubileuszowej, jednakże obudował je szerokim komentarzem. Warto zaznaczyć, że podkreślił w liście pewną wspólnotę poglądów ze swym krakowskim adresatem. Napisał wręcz o autorze Dziejów Polski $w$ zarysie, że jego „zacne intencje aż nazbyt dobrze rozumiem” ${ }^{\text {. }}$. Mimo to uznał, że Bobrzyński spogląda na dzieje z perspektywy polityka, nie zaś historyka, dlatego jego dzieło tchnie „zanadto energicznym duchem inkwizytorskim"32. Pod koniec listu Plebański zdystansował się od jednostronnych interpretacji dziejów Polski - monarchicznej i republikańskiej.

W tym samym roku w przypisie będącym votum separatum redakcji „Biblioteki Warszawskiej” do artykułu recenzyjnego Historyi polskiej Szujskiego pióra Franciszka Krupińskiego (sygnowanego F.K.) Plebański zgłosił swoje uwagi dotyczące badań nad parlamentaryzmem polskim w XVII w. W kontekście tych rozważań szczególnie interesująca wydaje się zwłaszcza jedna z nich. Otóż pisząc o historiografii polskiej w XIX w., stwierdził, że już dawno przed „tak zwaną najnowszą szkołą” polscy historycy zeszli na manowce polityki, oddalając się od nauki. „Historycy nasi, zamiast historyi przeszłości poczęli pisać instrukcye dla polityki, prądami dzisiejszych interesów kierowanej. Tego politycznego blichtru nadużywała z pewną ostentacyą od r. 1830 r. równie szkoła republikańska jak i monarchiczna, z wielką szkodą dla gruntownego poznania i zrozumienia przeszłości naszej”33 - pouczał. W tych ramach sytuuje się więc również i „nowa szkoła” rodem z Krakowa, której aspiracje do „nowości” są, zdaniem redaktora „Biblioteki”, mocno na wyrost, a ich badania skażone anachronizmem. Szujski i Bobrzyński, dając przykład innym, wprowadzili bowiem do historii Polski pojęcia, które były tam nieobecne. W poglądach historycznej szkoły monarchicznej „leży dużo anachronizmu, a jeszcze więcej niczem nie usprawiedliowionej doktryneryi" ${ }^{34}$. Tym samym krakowscy dziejopisowie popełnili „niesprawiedliwość względem przeszłości naszej”, wywiedli,

${ }^{29}$ J.K. Plebański, O pamiętnikach historycznych..., s. 481-482.

30 A.F. Grabski, Jeszcze o sporach...

${ }^{31}$ J.K. Plebański do M. Bobrzyńskiego, Izdebno, 16 III 1880 r., cyt. za: przedrukiem w: A.F. Grabski, Jeszcze o sporach..., Aneks III, s. 326.

32 Tamże.

33 J.K. Plebański, przyp. do: F. K[rupiński], „Historyi polskiej treściwie opowiedzianej ksiag dwanaście”. Napisał prof. Józef Szujski, „Biblioteka Warszawska” 1880, t. 4, s. 302.

34 Tamże. 
jak ironicznie stwierdził Plebański, nawiązując do słynnego tekstu Szujskiego z 1877 r., „»fałszywą politykę« z »fałszywej historyi«"35. Można przypuszczać, że wykazanie fundamentalnych różnic między historykiem a politykiem, jakie dał Plebański w artykule z księgi jubileuszowej Kraszewskiego, było odpowiedzią nie tylko na dzieło Bobrzyńskiego, ale i wcześniejsze wystąpienie Szujskiego O fałszywej historyi jako mistrzyni fałszywej polityki (Kraków 1877). Warto zaznaczyć, że w tej notce Plebański, podobnie jak w liście do Bobrzyńskiego, ponownie zdystansował się tak od nurtu republikańskiego, jak i monarchicznego w polskiej historiografii.

W następnym roku Plebański przedstawił w „Bibliotece Warszawskiej” recenzję pierwszego tomu Sejmu Czteroletniego Waleriana Kalinki. Powtarza się tu ten sam wątek krytyki: mimo wielkiego trudu badawczego ks. Kalinka uległ swym poglądom politycznym. Plebański podkreślił: „historya powinna być, w myśl wymownego Rzymianina, mistrzynią późniejszych pokoleń; ale nigdy rzecznikiem téj lub owéj doktryny politycznej"36. Niestety autor recenzowanej pracy poszedł drogą polityka w swej interpretacji zebranego materiału źródłowego. Historia stała się dla niego jedynie służebnicą jego własnej doktryny politycznej. Kalinka w badanych wydarzeniach szukał argumentacji dla swych przekonań, jednocześnie ze stanowiska tychże przekonań oceniając sytuację w Rzeczypospolitej doby Sejmu Czteroletniego. Poszukiwanie tych argumentów przysłoniło mu jego obowiązek historyka - dążenia do prawdy. $Z$ tego powodu nakreślony przez niego obraz omawianych wydarzeń jest zbyt jednostronny. Skupił się on bowiem przede wszystkim na analizie zabiegów dyplomatycznych, pomijając poruszane na sejmowym forum sprawy wewnętrzne państwa. Dlatego też obraz Sejmu Czteroletniego został odmalowany w przesadnie ciemnych barwach. Ponadto autor nazbyt starał się w swej książce bronić władzy królewskiej przed pragnącym dobra ludu sejmem. Przekonanie Plebańskiego było w tej materii zgoła inne: „nam się zdaje, że nawet najracyonalniejsza polityka nie każe z miłości rygoru władzy wyrzekać się praw, jakie wolnemu ludowi służą"37 (w tej obronie sejmu jest oczywiście pewna doza prezentyzmu). Redaktor „Biblioteki Warszawskiej” zaznaczył, że nie boi się prawdy historycznej, jakąkolwiek by ona nie była. Stanowi ona, jego zdaniem, najlepsze lekarstwo na różne dolegliwości narodu. Musi być ona jednakże ustalana na drodze „ściśle naukowej krytyki”38. Tej jednak Kalinka się sprzeniewierzył, idąc raczej za mirażem swej politycznej wizji.

Mimo to Plebański uznawał dzieło Kalinki za jedno z najwyższych osiągnięć polskiej historiografii w ostatnich latach. Jeszcze w 1890 r. na marginesie innego

35 Tamże, s. 303.

36 J.K. Plebański, „Sejm czteroletni”, napisał X. Waleryan Kalinka, ze Zgromadzenia Zmartwychwstania Pańskiego. Tom I. Kraków, 1880. Wydanie 2-gie. Lwów, 1881, str. VIII, 583. Tom II, Lwów, 1881, str. VII, 255, „Biblioteka Warszawska” 1881, t. 4, s. 298.

37 Tamże, s. 305.

38 Tamże, s. 307. 
artykułu wspomniał księdza zmartwychwstańca jako autora książki o Sejmie Czteroletnim, „którego stronę historyczną nieodżałowany ks. Kalinka z takiem mistrzostwem był opisał"39. Zdaje się, że Plebański przywiązywał dużą wagę do faktograficznych ustaleń Kalinki. Nie mógł jednak przystać na sposób ferowania przez niego historycznych ocen i sądów.

Warto tu dodać, że w t. 1 „Biblioteki Warszawskiej” z 1881 r. pojawiła się informacja o wydaniu książki Stanisława Smolki Mieszko Stary i jego wiek, której fragment pojawił się w warszawskim periodyku w poprzednim roku. Anonimowy autor notatki - w którym domyślać się można samego redaktora ${ }^{40}$ - wysoko ocenił pracę tego historyka, określając ją, obok dzieła Kalinki, jako najważniejszą książkę polskiej historiografii w ostatnim czasie. W krótkim omówieniu wskazano, że Smolka opowiedział się za wcześniej wypracowaną periodyzacją dziejów Polski, w której wyróżniano osobny okres „dzielnic książęcych”, w przeciwieństwie do Michała Bobrzyńskiego, który odniósł „tak zwaną epokę Polski w podziałach w jednej połowie do wprowadzonej przez siebie epoki patryarchalnej, w drugiej zaś do równie przez siebie stworzonej epoki patrymonialnej”" ${ }^{31}$. Jak widać, Plebański nie omieszkał wykorzystać okazji do zakwestionowania periodyzacji zaproponowanej przez Bobrzyńskiego. Ponownie kierując pod jego adresem zarzut prezentyzmu, przeciwstawiał mu Smolkę, który gruntownie przebadał źródła, dzięki czemu mógł postawić śmiałe hipotezy. Na koniec Plebański stwierdzał: być może inni historycy dokonają jeszcze wielu odkryć w zakresie dziejów Polski doby rozbicia dzielnicowego, natomiast „grunt historyczny téj epoki przez p. Smolkę wszechstronnie zbadany zapewne, zachwianym nie będzie" ${ }^{22}$. Smolka pozostał wierny metodzie naukowej, jego dzieło może być więc z powodzeniem przedstawiane jako wzór pracy badawczej, w przeciwieństwie do Dziejów Polski w zarysie. Wydaje się więc, że dla Plebańskiego Smolka - przynajmniej Smolka z Mieszka Starego - ze względu na odmienność swej metody badawczej nie powinien być wliczany w poczet „nowszej szkoły historycznej” ${ }^{3}$.

39 J.K. Plebański, rec. t. 9 Volumina Legum: Prawa, konstytucje i przywileje Królestwa polskiego, W. ks. litewskiego i wszystkich prowincyi należacych, na walnych sejmach koronnych od sejmu wiślickiego roku pańskiego 1347, aż do ostatniego sejmu uchwalone..., „Biblioteka Warszawska” 1890, t. 1, s. 132. Podobnie w pozytywnym świetle przedstawił dorobek Kalinki we wspomnianej wyżej recenzji książki W. Abrahama.

${ }^{40}$ Znów - decyduje podobieństwo stylu i odwołań historiograficznych.

${ }^{41}$ [J.K. Plebański], [Informacja o wydaniu Mieszka Starego Stanisława Smolki], „Biblioteka Warszawska" 1881 , t. 1, s. 325.

${ }^{42}$ Tamże, s. 326.

43 Warto zauważyć, że jakkolwiek historycy historiografii zwykli widzieć Smolkę jako przedstawiciela krakowskiej szkoły, nie jest to jednak zasadą - Krzysztof K. Daszyk nie uznaje Smolki jako jej reprezentanta; zob. tenże, Historiografia krakowska doby zaborów. Główne kierunki badań i interpretacji narodowej przeszłości, w: Historiografia Krakowa i jej twórcy. Materiały sesji naukowej odbytej 25 czerwca 2005 roku dedykowanej pamięci prof. Józefa Mitkowskiego w 25. rocznice śmierci, Kraków 2005, s. 49. 
Uwaga, nieco aluzyjna, pod adresem krakowskiej szkoły pojawia się również we wstępie Plebańskiego do edycji broszury politycznej z XVII w. pt. Recepta na to, abyśmy się dlugo w ojczystej ziemi osiedzieli. Już sam przedmiot tej edycji miał wyraźny wydźwięk polemiczny. Zdaniem Plebańskiego bowiem Recepta świadczy o istnieniu w Rzeczypospolitej w XVII w., uznawanym za okres ogólnego upadku państwa, również w sferze intelektualnej, ożywczych prądów umysłowych, których przedstawiciele zabiegali o naprawę ustroju. Plebański starał się więc przeciwstawić głos źródła historycznego upraszczającym obraz epoki historykom. W tym, jak sądzę, historykom krakowskim ${ }^{44}$. Potwierdzeniem tego jest jego komentarz, w którym po raz kolejny wypominając historykom krakowskim "grzech” ahistoryzmu, argumentował, że proponowane przez nich sposoby ratunku Rzeczypospolitej, takie jak wytworzenie ,jak najsilniejszych organów policyjnych”, były oderwane od realiów ustrojowych dawnego państwa i stanowiły raczej projekcję ich poglądów politycznych. Tymczasem przeszłe wieki „z wszystkiemi swemi odrębnemi ideami i namiętnościami politycznemi utonęly $\mathrm{w}$ falach przeszłości; historya odkrywa i bada bowiem te idee, stanowiące żywotne siły danej chwili, które dopominały się urzeczywistnienia swego w sposób normalny, bez narzucającej się przemocy brutalnych organów policyi lub absolutnej opieki wszechwładztwa państwowego" ${ }^{45}$. Zdaniem Plebańskiego historyk nie powinien narzucać przeszłości swych własnych przekonań, lecz badać pojawiające się w „organicznym rozwoju ludzkości” idee poruszające dziejowe podmioty do działania. Zadanie dziejopisarza widział on w odnajdywaniu momentu genezy tych idei i śledzeniu ich losów. Tymczasem historycy krakowscy, zdawał się sądzić, chcieliby, aby to państwo za każdym razem narzucało swe idee społeczeństwu i właśnie tylko w organach państwa poszukują jedynego słusznego miejsca narodzin idei.

O tym, jak dalece Plebański postrzegał „nową szkołę historyczną” przez pryzmat metodologii (a właściwie błędu ahistoryzmu), świadczy fakt, że z grona tego wykluczał (o czym była już mowa) Stanisława Smolkę, włączał zaś - inaczej niż przyjmuje historiograficzna tradycja - Wincentego Zakrzewskiego. Zarzuty, jakie Plebański formułował w związku z jego książką o Stefanie Batorym są niemal tożsame z tymi, jakie stawiał dziełu Kalinki.

Przypadek Zakrzewskiego jest niejako odwrotnością przypadku Smolki - tym razem mamy historyka w literaturze zazwyczaj niewiązanego $\mathrm{z}$ krakowską szkołą, ale,

${ }^{44}$ Być może m.in. taki cel - poza poznawczym - stał również za edycją wierszy Olbrychta Karmanowskiego. We wstępie Plebańskiego można przeczytać, że wiersze Karmanowskiego stanowią dowód żywotności polszczyzny w XVII w. oraz ciągłości piśmiennictwa polskiego w XVI-XVII w.; J.K. Plebański, Olbrychta Karmanowskiego poety wieku XVII-ego wiersze różne zebrał..., „Biblioteka Warszawska" 1890 , t. 2, s. 13. I ta edycja ukazała się osobno w poszerzonej wersji w $1890 \mathrm{r}$. w Warszawie.

${ }^{45}$ Tenże, Wstęp, w: Recepta na to, abyśmy się długo w oyczystej ziemi osiedzieli. A. 1682. Dokument historyczny do dziejów polskich w wieku XVII. Z rękopisu podał Józef Kazimierz Plebański, Warszawa 1887 (odb. z „Biblioteki Warszawskiej”), s. 4. 
jak się zdaje, przynależnego do niej w optyce warszawskiego uczonego ${ }^{46}$. Plebański oskarżył Zakrzewskiego o to, że stawiane przez niego pytania badawcze mieszczą się w kwestionariuszu nie historyka, lecz polityka. Krakowski dziejopis chciał znaleźć odpowiedź na pytanie, czy Batory potrafił znaleźć dla Rzeczypospolitej takie wysokie cele, które cały naród - lub jego większa część - mógłby uznać za swoje własne. Jeżeli zaś król takie cele znalazł i zrobił wszystko, co mógł, by pociągnąć za sobą naród, ten jednak nie poszedł za nim lub go nie zrozumiał, znaczyć to mogło tyle, że Polska już wówczas, w drugiej połowie XVI w. weszła na drogę swego upadku. „Problemat” Zakrzewskiego komentuje Plebański następująco: „publicystyka nowsza głosi z taką energią wyrok, obwieszczający gotowy upadek narodu polskiego przy każdym tryumfie przemocy w czasach odleglejszych jeszcze niż epoka Batorego, że chroniąc się przed temi ekspektoracyami politycznemi do świątyni nauki historyi, przychodzimy do przekonania, że zadanie, na które p. Zakrzewski w tej części swojej pracy chciał odpowiedzieć, nie jest zadaniem historyi; ale należy do kombinacyi i rachuby politycznej, bo pragnie uczyć nas tego, co Batory powinien był przedsiębrać w celach wyższych, a zaniedbuje do pewnego stopnia oświecić nas o istotnem położeniu ówczesnych stosunków" ${ }^{\prime 7}$. Tym samym Plebański niejako odmówił książce Zakrzewskiego miana dzieła naukowego, sprowadzając ją jedynie do rangi publicystki. Po raz kolejny jeden z krakowskich historyków przeniósł na przeszłość swe własne polityczne fantazje, porzucając drogę prawdziwej nauki. Według redaktora „Biblioteki Warszawskiej” zadaniem nowo obranego króla winno się stać sumienne wykonywanie obowiązków, które otrzymał w spadku po swym poprzedniku, zgodnych $\mathrm{z}$ aktualnym stopniem rozwoju państwa. Powodu do chwały Batorego szukałby więc raczej nie w tym, czy starał się zaszczepić narodowi jakieś nowe, wyższe idee, lecz czy wniknął on w aktualne jego cywilizacyjne potrzeby. Plebański postrzegał więc panowanie Batorego w jego historycznych uwarunkowaniach, Zakrzewski zaś, zdaniem warszawskiego uczonego, chciałby, by król realizował jakieś nieznane wówczas idee - najpewniej idee samego historyka.

W omawianej recenzji Plebański zawarł ponadto ciekawą uwagę o charakterze ogólnym. Podkreślił mianowicie, że badacz zgłębiający „istotę Sejmowania nie może opierać się na dzisiejszej teoryi nauk politycznych o zasadach reprezentacyi narodowej ani też na praktyce obrad ludowych w republikach starożytnych; ale na gruncie zjazdów prowincyonalnych, powszechnych w wiekach średnich"48.

${ }^{46}$ Chociażby J. Maternicki wyraźnie zaznacza liczne odmienności poglądowe Zakrzewskiego w porównaniu do szkoły krakowskiej; zob. tenże, Zmierzch szkoły krakowskiej..., s. 166-167. Zob. też bardzo ciekawą wypowiedź Zakrzewskiego o tym, czym jest „nowa szkoła historyczna” w Polsce; tenże, Xawery Liske 1838-1891. Wspomnienie pośmiertne, Kraków 1891.

47 J.K. Plebański, rec.: „Stefan Batory. Przegląd historyi jego panowania i program dalszych nad niq badań. Z powodu 300-letniej rocznicy śmierci króla Stefana”. Napisat Wincenty Zakrzewski, „Biblioteka Warszawska” 1887, t. 2, s. 302.

48 Tamże, s. 306. 
Powtarza się więc tu uwaga, że uczciwy historyk nie może przykładać do przeszłych epok nieznanych im kategorii. Musi za każdym razem uwzględniać historyczne uwarunkowania interesujących go zjawisk. Zdaniem Plebańskiego bowiem „przeraża” i „oburza” obecny jeszcze w XIX w. terror, jakim rządowe większości potrafią prześladować słabsze mniejszości. Dlatego też „nie możemy bić już bez zastrzeżeń bałwochwalczem czołem przed tą formą reprezentacyi narodowej, na jaką się dotychczasowa praktyka rządowa zdobyła, bo ufamy rządom Opatrzności w dziejach, że ona obmyśli skuteczny środek przeciw poniewieraniu idei sprawiedliwości - choćby w brew [sic!] doktrynie apostołów zbawczej wszechwładzy organów policyjnych"49. Jest w tym zdaniu aluzyjny przytyk pod adresem krakowskich historyków, szczególnie Bobrzyńskiego, ale i przestroga, dodajmy: tak przed absolutyzmem, jak i anarchiczną formą rządów. Ale jest i tutaj, wbrew metodologicznym przekonaniom Plebańskiego, ahistoryczne przecież rzutowanie wstecz własnych (politycznych) obaw.

Zawoalowaną krytykę krakowskiej szkoły można, jak sądzę, odnaleźć również w innych tekstach. Ciekawie prezentuje się tutaj pochwalna ocena Szkót historycznych $w$ Polsce Władysława Smoleńskiego, której anonimowego autora ze względu na styl i charakterystyczne odwołania historiograficzne można widzieć w Plebańskim ${ }^{50}$. W notatce zawarto następującą uwagę o pojęciu szkoły historycznej: „widzimy, że sz[anowny] autor, gardzący przesadą i affektacyą, którą się zastawiać zwykła blaga pseudo uczonych, nie uważał nazwy "Szkoły historyczne« za odpowiadającą swemu przekonaniu i poważnemu rozbiorewi [sic!] przedmiotu" ${ }^{1}$. W „bladze pseudo-uczonych” trzeba widzieć, jak mniemam, krakowskich historyków, którzy sami, zdaniem Plebańskiego, przypisali sobie miano „nowej szkoły historycznej”. Zwraca również uwagę krytyka stosowania określenia „szkoły historycznej" wobec nurtów tworzących w XIX w. polską historiografię. W przypisie autor notki zauważył, że „w powszednim u nas samochwalstwie liczymy zwykle tyle szkół historycznych, ilu literatów ogłasza prace z historyi polskiej” ${ }^{2}$. „Literatów”, nie zaś „dziejopisów”. Na koniec wyrażono nadzieję, że praca Smoleńskiego o ks. Kalince ukaże się, wzorem Szkół historycznych w Polsce, w postaci osobnej

49 Tamże.

50 [J.K. Plebański], [Informacja o wydaniu Szkół historycznych w Polsce Władysława Smoleńskiego], „Biblioteka Warszawska” 1887, t. 2, s. 335-336. W. Smoleński w Szkołach historycznych wspomina o Plebańskim dwukrotnie. Najpierw podkreśla jego brak wpływu na praktykę dziejopisarską w Warszawie - i to mimo prowadzenia seminarium w Szkole Głównej, a poza tym przedstawia go jako przeciwnika Buckle’owskiego konceptu praw w dziejach; zob. W. Smoleński, Szkoły historyczne w Polsce (główne kierunki poglądów na przeszłość), Warszawa 1986, s. 80-81, 130. Jest więc to sąd niespecjalnie (z perspektywy Smoleńskiego) pochlebny. Mimo to Plebański nie wahał się ocenić wysoko jego pracy.

${ }^{51}$ [J.K. Plebański], [Informacja o wydaniu Szkót historycznych w Polsce Władysława Smoleńskiego]..., s. 335 .

${ }^{52}$ Tamże. 
odbitki, gdyż jest najlepszym, najsprawiedliwszym tekstem poświęconym temu historykowi, jaki dotąd napisano. A przecież był to sąd krytyczny. Plebański niewątpliwie mógł się podpisać pod zdaniem z tej pracy, że ks. Kalinka „, historykiem według wymagań nauki nie był” ${ }^{33}$, co, choć nie tak dobitnie, redaktor „Biblioteki Warszawskiej" sam stwierdził w recenzji pracy o Sejmie Czteroletnim.

Swoje rozważania nad dorobkiem krakowskiej szkoły historycznej Plebański niejako podsumował w dwóch tekstach: Krytyce historycznej w szkole wychowawczej (1888) oraz w recenzji książki Władysława Abrahama Organizacya Kościoła $w$ Polsce do połowy wieku XII (1891).

W Krytyce Plebański występuje przeciwko „tzw. nowszej szkole historycznej”, pisząc, że o ile jeszcze do niedawna wielu rodzimych dziejopisarzy idealizowało przeszłość, o tyle ci „nowsi” prześcigają się w zawodach w jej poniewieraniu. Co gorsza, taki karykaturalny, jednostronny obraz polskich dziejów zaczął przenikać do szkół ${ }^{54}$. Nowi historycy ogłosili zwrot w ojczystej historiografii, lekceważąc dorobek swych poprzedników i same dzieje Polski. „Prawiebyśmy dziś złorzeczyć gotowi owej »ślepocie« minionych dawno wieków za to, że nie postępowały one według, rady i wedle rachuby polityków dzisiejszych!"55 - ironizował. Krytycy polskiego dziejopisarstwa nie chcą zauważyć, że ich poprzednicy tworzyli swe prace zgodnie z ówczesnymi wymogami metody historycznej, która zdążyła się przecież od tej pory rozwinąć, przede wszystkim dzięki staraniom Bartholda Georga Niebuhra, Gustawa Stenzla, Georga Heinricha Pertza, Georga Waitza i Leopolda von Ranke. Podkreślał Plebański, że to w Niemczech powstała ,już za naszej pamięci nowsza szkoła historyczna, zasługująca dopiero na to miano" ${ }^{\text {" }}$. W tym czasie w Polsce historycy działali w różnych kierunkach, które na miano szkoły, zdaniem Plebańskiego, nie zasługują. Warszawski historyk w swym artykule wziął w obronę dorobek historyków o zdecydowanie różnych zapatrywaniach na przeszłość Polski - Adama Naruszewicza, Tadeusza Czackiego, Hugona Kołłątaja, Stanisława Staszica, Michała Wiszniewskiego, Joachima Lelewela, Karola Szajnochy, Antoniego Zygmunta Helcla i innych, którzy działali przed narodzinami tzw. krakowskiej szkoły. Jej samej zarzucił „niewykończony wszechstronnie, nie wycieniowany sumiennie obraz przeszłości naszej, obraz przeładowany w wielu miejscach zbyt jaskrawymi barwami, owiany grozą oburzenia i nienawiści za to, że nie jest takim, jakimbyśmy go według naszych potrzeb dzisiejszych widzieć pragnęli”" ${ }^{37}$.

53 W. Smoleński, Stanowisko Waleryana Kalinki w historyografii polskiej, Warszawa 1887, s. 43.

${ }^{54}$ Zauważmy, że Bobrzyński dopiero w 1891 r. zostanie wiceprezydentem Rady Szkolnej Krajowej, Zakrzewski w tym samym roku wyda zaś pierwszy tom swego podręcznika historii dla gimnazjów.

${ }_{55}$ J.K. Plebański, Krytyka historyczna..., cz. 1, s. 4.

56 Tamże.

57 Tamże, s. 5. Obie części tego artykułu (nr 14, s. 3-6; nr 15, s. 1-3) w gruncie rzeczy traktują o ślepocie historyków, którzy za cel wzięli sobie biczowanie przeszłości Polski za jej błędy oraz o przenikającym do dydaktyki zgubnym wpływie tej wizji ojczystych dziejów na młodzież. 
Ponownie powtarzają się tu zarzuty przykładania do przeszłości swych własnych poglądów, idei oraz - tym razem bardziej wyeksponowany - zarzut o przedstawianie rodzimych dziejów w sposób przejaskrawiony, w nadmiernie oskarżycielskim tonie.

Recenzję książki Władysława Abrahama można uznać za zwieńczenie sporu Plebańskiego z krakowską szkołą, której ostatecznie odmówił wręcz tego zaszczytnego miana. Jego zdaniem samozwańcza „szkoła krakowska [...] przez to, że według dzisiejszych idei politycznych pragnęłaby oceniać rozwój stosunków dawno minionej przeszłości naszej, nową "Szkołą» historyczną bynajmniej nie zostanie"58. Miano szkoły historycznej Plebański zdawał się rezerwować dla kierunku, który kształci badaczy przeszłości, pragnących ją zrozumieć, zmierzających do prawdy historycznej, nie dla politycznej koterii, wysługującej się przeszłością dla swych partykularnych celów. Prace badawcze „odznaczają się tym większą powagą naukową, im skromniej obwołują tryumfy »nowej szkoły historycznej «, bo wtedy zostają w racyonalniejszym związku z naukowym postępem historyografii europejskiej w ogóle" 59 - pisał. Na pochwałę zasługują przede wszystkim te prace, których autorzy pragną metodologicznie usystematyzować badania historyczne, nie zaś oświadczają zwycięstwo jakiejś nowej szkoły w historiografii. Trzeba przyznać, że równie krytycznie Plebański obszedł się z drugą ówczesną polską szkołą historyczną - warszawską ${ }^{60}$. Obie szkoły - czy może nawet, idąc za myślą Plebańskiego, „fakcje” - zamiast wspólnie wznosić „świątynię Prawdy” ${ }^{61}$ wolą ze sobą „bez przyczyny” wojować. Takie postępowanie, przestrzegał, może tylko rozluźnić nasze związki z dziejopisarstwem europejskim. Na szczęście, według Plebańskiego, autor recenzowanej książki zachował dystans wobec haseł „zawistnych sobie bez przyczyny rzekomych szkół historyograficznych" ${ }^{62}$, nie zniżył się do słownych utarczek, trwając przy ideale autonomicznej nauki.

Warto zauważyć, że ten ostatni tekst został ogłoszony w 1891 r., a więc już po głównych atakach szkoły warszawskiej. W 1890 r. na Zjeździe Historyków we Lwowie Tadeusz Korzon wystąpił z oskarżycielskim pod adresem środowiska krakowskiego tekstem pt. Błędy historiografii naszej w budowaniu dziejów Pol$s k i^{63}$. Być może sprowokowało ono Plebańskiego do zajęcia własnego stanowiska

58 J.K. Plebański, rec.: Organizacya Kościoła w Polsce do połowy wieku XII. Napisał prof. dr. Władysław Abraham. We Lwowie 1890. Nakładem autora. 8, XII, 259 str., „Biblioteka Warszawska” 1891 , t. 1, s. 148 .

59 Tamże.

60 Na obecnym stanie badań nie można wiele powiedzieć o stosunku Plebańskiego do tej grupy uczonych, z którą przynajmniej dzielił miejsce swej działalności naukowo-zawodowej.

61 J.K. Plebański, Lekcya wstępna metodologii i encyklopedyi nauk akademickich, Warszawa 1862, s. 1-2.

62 Tenże, rec.: Organizacya Kościoła w Polsce..., s. 149.

63 W tym samym roku ukazała się znana satyra Asnyka Historyczna nowa szkoła; zob. A.F. Grabski, „Podpalacze” przeciw „lidze brandmajstrów”..., s. 352-353; J. Kolbuszewska, Spór o wizję..., s. 251-253. 
i wskazania na pozytywny przykład praktyki dziejopisarskiej, jakim była dla niego książka Władysława Abrahama - historyka ze Lwowa. Ten wybór „trzeciej strony” również mógł być nieprzypadkowy ${ }^{64}$.

Przedstawiona krytyka Plebańskiego może wydawać się zaskakująca o tyle, że jego wizja świata i człowieka w zasadzie nie była radykalnie odmienna od optyki jego krakowskich kolegów - wręcz przeciwnie, zwraca uwagę raczej jej podobieństwo. Łączyły je konserwatyzm i (umiarkowany) monarchizm, ewolucjonizm, niechęć czy nawet wrogość w stosunku do narodowej irredenty, krytyka ruchów socjalistycznych. Trzeba również pamiętać, że sam Plebański w liście do Bobrzyńskiego podkreślał pokrewieństwo swojej postawy politycznej z poglądami autora Dziejów Polski w zarysie. Z kolei prowidencjalistyczna wizja dziejów zbliżała Plebańskiego do Szujskiego i Kalinki.

Kluczowe dla zrozumieniu tej krytyki wydają się przede wszystkim dwa czynniki. Pierwszy $\mathrm{z}$ nich można dostrzegać $\mathrm{w}$ różnicy historycznego doświadczenia. Inaczej na kwestię silnej, absolutystycznej władzy musiał zapatrywać się mieszkaniec Królestwa Polskiego po 1863 r., inaczej zaś mieszkańcy liberalnej monarchii habsburskiej, szczególnie po 1867 r. Likwidacja Szkoły Głównej Warszawskiej, gdzie Plebański wykładał historię, była zapewne dla niego dużym ciosem ${ }^{65}$. Jedenaście lat później jako redaktor ważnego periodyku musiał się zaś mierzyć $\mathrm{z}$ cenzurą, doskwierał mu brak możliwości zrzeszania się w ramach towarzystw naukowych, drżał o losy oświaty w Królestwie, co ukazuje jego korespondencja ${ }^{66}$. Doświadczał więc tego, jak silna władza potrafi hamować rozwój nauki i całego społeczeństwa. Stąd też powracające w jego pismach ostrzeżenia przed „apostołami zbawczej wszechwładzy policyjnych organów". Można więc przypuszczać, że konfrontacja z samodzierżawiem uwrażliwiała Plebańskiego (skądinąd przeciwnika irredenty) na niebezpieczeństwa zawarte w idei silnego państwa, którego rzecznikami byli znający liberalną monarchię Galicjanie. W perspektywie historyka warszawskiego silne państwo było synonimem państwa policyjnego, które

${ }^{64}$ Można więc przypuszczać, że Plebański nie widział we Lwowie „szkoły historycznej”, porównywalnej z krakowską i warszawską czy też przynależnej do nurtu monarchicznego bądź republikańskiego. Historycy historiografii często wyrażali swe wątpliwości, czy w ogóle można mówić o szkole lwowskiej. Ostatnie głosy: J. Maternicki, Polskie szkoły historyczne we Lwowie w XIX w., w: Wielokulturowe środowisko historyczne Lwowa w XIX i XX w., t. 3, red. J. Maternicki, L. Zaszkilniak, Rzeszów 2005, s. 23-44; T. Pawelec, Szkoła czy środowisko? (Lwów i lwowscy historycy - uwagi metodologiczne), w: tamże, s. 46-60.

65 Zob. J.K. Plebański, Przed dwudziestu pięciu laty, „Tygodnik Ilustrowany” 1887, nr 255, s. 322-324; nr 256, s. 342-343.

${ }^{66}$ Biblioteka Jagiellońska, rkps 10110, List J.K. Plebańskiego do F. Papéego, 31 V 1887 r., k. 39r-40r. 
opierało się na wszechobecnej kontroli, hamowało rozwój twórczego ducha ludzkiego i moralny wzrost ludzkiej indywidualności, a tym samym stało na drodze postępu. Nie mógł więc odnaleźć w sobie entuzjazmu dla historycznego ideału rządnej monarchii, który podnosili Galicjanie, nieświadomi obserwowanych przez niego zagrożeń.

Krytyki Plebańskiego nie da się jednak wyjaśnić wyłącznie różnicą politycznego doświadczenia. Drugim czynnikiem, który decydował o jej kształcie, było bowiem jego wykształcenie. Wydaje się, że Plebański był pierwszym polskim historykiem uformowanym w duchu dojrzałego historyzmu i jego konsekwentnym wyznawcą. Do końca życia zachował admirację dla dokonań niemieckiej historiografii, jednocześnie zachowując dystans wobec jej nacjonalistycznych dążeń ${ }^{67}$. Zdaniem Plebańskiego historycy związani z krakowską szkołą anachronicznie interpretowali dzieje Polski, występując tym samym przeciwko jednej z najważniejszych reguł historyzmu. $\mathrm{W}$ jego ocenie $\mathrm{w}$ ten sposób znacząco ograniczyli oni poznawczą wartość swych dzieł, może znakomitych w przedstawieniu faktów, zafałszowanych jednak przez ich polityczne doktrynerstwo. Podkreślał, że było to postępowanie sprzeczne z zasadami nowoczesnego badania historii, której celem powinno być dążenie do Prawdy, którą Plebański pisał wielką literą, uważając się za jej wyznawcę. Mimo to nie można nie zauważyć, że i sam nie ustrzegł się w swych sądach tak krytykowanego przez siebie ahistorycznego rozumienia przeszłości.

Sprzeciw Plebańskiego budziła też rewolucyjna retoryka krakowskich historyków, którzy we własnym mniemaniu zrywali z poprzednimi generacjami polskich dziejopisarzy, ogłaszając narodziny nowej szkoły. I w tym wypadku, zdaniem Plebańskiego, krakowscy historycy popełnili anachronizm, oceniając swych poprzedników z perspektywy stanu metod badawczych i metodologii historii właściwiej dla drugiej połowy XIX w., nie zaś z perspektywy stanu historiografii właściwego dla historyków poprzednich dekad. Zlekceważyli również ich heurystyczny i analityczny trud. Wskazywał więc on na duchowych poprzedników szkoły krakowskiej w postaci nurtu monarchicznego polskiej historiografii. Stanął jednak w obronie nie tylko dorobku Naruszewicza i jego następców, ale również znajdującego się na antypodach wizji monarchicznej Lelewela i jego naśladowców, doceniając ich wysiłek badawczy i wkład w rozwój polskiej historiografii ${ }^{68}$. Tym samym ustawiał siebie samego niejako poza sporami o przeszłość Polski swego czasu. Dystansował się zarówno od kierunku monarchicznego, jak i republikańskiego w polskiej historiografii, tak samo od szkoły krakowskiej, jak i warszawskiej. Przyznawał więc sobie osobne, zapewne we własnym mniemaniu obiektywne miejsce w rodzimym dziejopisarstwie. Wydaje się, że poczuwał się raczej do wspólnoty

67 A. Rembowski, Józef Kazimierz Plebański. Wspomnienie pośmiertne, „Biblioteka Warszawska" 1897 , t. 3, s. 546-547.

${ }^{68}$ J.K. Plebański, Krytyka historyczna..., cz. 1, s. 4. 
z niemiecką szkołą, którą tak cenił i stawiał za wzór polskim dziejopisom. Jego samopostrzeganie się nie jest tu przecież bez znaczenia. Tak samo jak uznanie dla dokonań Rankego, Niebuhra i Mommsena ${ }^{69}$.

\section{Bibliografia}

\section{Źródła rękopiśmienne}

Biblioteka Jagiellońska, rkps 10110, List J.K. Plebańskiego do F. Papéego, 31 V 1887 r.

Biblioteka Publiczna m.st. Warszawy, akc. 102, J.K. Plebański, Historiografia polska, 1864 r.

Biblioteka Publiczna m.st. Warszawy, akc. 102, J.K. Plebański, O zadaniu dziejopisarstwa polskiego, $1857 \mathrm{r}$.

\section{Źródła drukowane}

M. Chyliński, Józef Szujski, „Biblioteka Warszawska” 1883, t. 2, s. 41-57

F. K[rupiński], „Historyi polskiej treściwie opowiedzianej ksiąg dwanaście”. Napisał prof. Józef Szujski, „Biblioteka Warszawska” 1880, t. 4, s. 296-313

J.K. Plebański, Demokracja w ustroju starożytnych państw greckich, „Kłosy” 1887, nr 1173, s. 405

[J.K. Plebański], [Informacja o wydaniu Mieszka Starego Stanisława Smolki], „Biblioteka Warszawska" 1881 , t. 1, s. $325-326$

[J.K. Plebański], [Informacja o wydaniu Szkót historycznych w Polsce Władysława Smoleńskiego], „Biblioteka Warszawska” 1887, t. 2, s. 335-336

J.K. Plebański, Krytyka historyczna w szkole wychowawczej, „Przegląd Literacki. Dodatek do »Kraju«" 1888, nr 14, s. 3-6; nr 15, s. 1-3

J.K. Plebański, Lekcya wstępna metodologii i encyklopedyi nauk akademickich, Warszawa 1862

[J.K. Plebański], [Nekrolog Józefa Szujskiego], „Biblioteka Warszawska” 1883, t. 1, s. 470-472

J.K. Plebański, przyp. do: F. K[rupiński], „Historyi polskiej treściwie opowiedzianej ksiag dwanaście”. Napisał prof. Józef Szujski, „Biblioteka Warszawska” 1880, t. 4, s. 302-303

J.K. Plebański, O historycznem znaczeniu Juliusza Cezara, cz. 1, „Biblioteka Warszawska” 1865, t. 3, s. $169-209,429-463$

J.K. Plebański, O pamiętnikach historycznych wydanych przez J.I. Kraszewskiego, w: Książka jubileuszowa dla uczczenia pięćdziesięcioletniej działalności literackiej J.I. Kraszewskiego, Warszawa 1880

J.K. Plebański, Olbrychta Karmanowskiego poety wieku XVII-ego wiersze różne zebrał..., „Biblioteka Warszawska" 1890 , t. 2, s. 1-40

J.K. Plebański, Przed dwudziestu pięciu laty, „Tygodnik Ilustrowany” 1887, nr 255, s. 322-324; nr 256, s. 342-343

J.K. Plebański, rec.: Organizacya Kościoła w Polsce do połowy wieku XII. Napisał prof. dr. Władysław Abraham. We Lwowie 1890. Nakładem autora. 8, XII, 259 str., „Biblioteka Warszawska” 1891, t. 1 , s. $148-172$

69 O Mommsenie i Niebuhrze zob. tenże, Historja Rzymska przez Teodora Mommsena. Przełożył na język polski T. Dziekoński, „Gazeta Polska” 1867, nr 279-282; 1868, nr 9; o Rankem zob. [J.K. Plebański], [Nekrolog Leopolda von Ranke], „Biblioteka Warszawska” 1886, t. 2, s. 461-462; A. Rembowski, dz. cyt. 
J.K. Plebański, rec. t. 9 Volumina Legum: Prawa, konstytucje i przywileje Królestwa polskiego, W. ks. litewskiego $i$ wszystkich prowincyi należacych, na walnych sejmach koronnych od sejmu wiślickiego roku pańskiego 1347, aż do ostatniego sejmu uchwalone..., „Biblioteka Warszawska” 1890 , t. 1, s. $123-132$

J.K. Plebański, rec.: „Sejm czteroletni”, napisał X. Waleryan Kalinka, ze Zgromadzenia Zmartwychwstania Pańskiego. Tom I. Kraków, 1880. Wydanie 2-gie. Lwów, 1881, str. VIII, 583. Tom II, Lwów, 1881, str. VII, 255, „Biblioteka Warszawska” 1881, t. 4, s. 297-310

J.K. Plebański, rec.: „Stefan Batory. Przeglad historyi jego panowania i program dalszych nad niq badań. Z powodu 300-letniej rocznicy śmierci króla Stefana". Napisał Wincenty Zakrzewski. Wydanie poprawne i uzupetnione dodatkami. W Krakowie, nakt. G. Gebethnera i Sp., 1887, str. IV, 160, „Biblioteka Warszawska” 1887, t. 2, s. 299-307

J.K. Plebański, rec.: Wiktor Czajewski: „Rys dziejów naszych”. Polska za Piastów, z mapką Szlązku. Warszawa 1887, str. 139, „Biblioteka Warszawska” 1887, t. 1, s. 268-273

J.K. Plebański, Wstęp, w: Recepta na to, abyśmy się długo w oyczystej ziemi osiedzieli. A. 1682. Dokument historyczny do dziejów polskich w wieku XVII. Z rękopisu podał Józef Kazimierz Plebański, Warszawa 1887

A. Rembowski, Józef Kazimierz Plebański. Wspomnienie pośmiertne, „Biblioteka Warszawska” 1897, t. 3, s. $545-557$

W. Smoleński, Stanowisko Waleryana Kalinki w historyografii polskiej, Warszawa 1887

W. Smoleński, Szkoły historyczne w Polsce (główne kierunki poglądów na przeszłość), Warszawa 1986

Wiadomości bieżace, naukowe, literackie, artystyczne i społeczne [informacja o wydaniu Opowiadań i roztrzasań historycznych J. Szujskiego], „Biblioteka Warszawska” 1881, t. 4, s. 480-481

Z pod Wawelu [informacja o wydaniu Polaków i Rusinów w Galicyi J. Szujskiego], „Biblioteka Warszawska" 1882 , t. 2, s. 304-306

W. Zakrzewski, Xawery Liske 1838-1891. Wspomnienie pośmiertne, Kraków 1891

\section{Opracowania}

J.R. Błachnio, „Biblioteka Warszawska”: forum polskiej filozofii w latach 1841-1915, Bydgoszcz 1999

K.K. Daszyk, Historiografia krakowska doby zaborów. Główne kierunki badań i interpretacji narodowej przeszłości, w: Historiografia Krakowa i jej twórcy. Materialy sesji naukowej odbytej 25 czerwca 2005 roku dedykowanej pamięci prof. Józefa Mitkowskiego w 25. rocznicę śmierci, Kraków 2005, s. 29-62

R. Ergetowski, Studia J.K. Plebańskiego i pierwsze lata jego nauczycielskiej pracy, w: tenże, Silesiaca. Biblioteki, uczeni, studenci, wybór i wstęp E. Libura, Wrocław 2005, s. 71-129

A.F. Grabski, Historiografia polska wobec Leopolda von Ranke, „Przegląd Zachodni” 1987, nr 5-6, s. $167-178$

A.F. Grabski, Jeszcze o sporach wokół „Dziejów Polski w zarysie”, w: tenże, Perspektywy przeszłości. Studia i szkice historiograficzne, Lublin 1983, s. 279-320

A.F. Grabski, „Podpalacze” przeciw „lidze brandmajstrów”, w: tenże, Perspektywy przeszłości. Studia i szkice historiograficzne, Lublin 1983, s. 342-412

A.F. Grabski, Spór o prawa dziejowe. Kontrowersje wokót Henry’ego Thomasa Buckle’a w Polsce $w$ dobie pozytywizmu, Lublin 2002

A.F. Grabski, Z zagadnień stosunków polsko-niemieckich $w$ zakresie historiografii drugiej połowy $X X$ w. [sic!, powinno być: XIX w.], „Kwartalnik Historii Nauki i Techniki” 29, 1984, nr 2, s. 323 $-344$

G.G. Iggers, Historiografia XX wieku. Przegląd kierunków badawczych, tłum. A. Gadzała, Warszawa 2010

J. Kolbuszewska, Mutacja modernistyczna w historiografii polskiej (przełom XIX i XX w.), Łódź 2005 
J. Kolbuszewska, Spór o wizję dziejów, metodę, wartości - Tadeusz Korzon wobec „krakowskiej szkoły historycznej", w: Krakowska szkoła historyczna a Polskie Towarzystwo Historyczne. Studia historiograficzne, red. P. Biliński, P. Plichta, Kraków 2017, s. 241-254

B. Krzemieńska-Surowiecka, Polemika wokót „Dziejów Polski w zarysie” Michała Bobrzyńskiego (w latach 1879-1890), „Zeszyty Naukowe Uniwersytetu Łódzkiego. Seria 1. Nauki Humanistyczno-Społeczne" 1956, nr 4, s. 107-130

Z. Libiszowska, Józef Kazimierz Plebański (1831-1896), „Zeszyty Naukowe Uniwersytetu Lódzkiego. Seria 1. Nauki Humanistyczno-Społeczne" 1964, nr 4, s. 74-106

J. Maternicki, Historia i życie narodu. Poglądy i postawy historyków polskich XIX i XX w., Rzeszów 2009

J. Maternicki, Polskie szkoły historyczne we Lwowie w XIX w., w: Wielokulturowe środowisko historyczne Lwowa w XIX i XX w., t. 3, red. J. Maternicki, L. Zaszkilniak, Rzeszów 2005, s. 23-44

J. Maternicki, Warszawskie środowisko historyczne 1832-1869, Warszawa 1970

J. Maternicki, Zmierzch szkoły krakowskiej i opozycja historyków warszawskich, w: tenże, Kultura historyczna dawna i wspótczesna. Studia i szkice, Warszawa 1979

T. Pawelec, Szkoła czy środowisko? (Lwów i lwowscy historycy - uwagi metodologiczne), w: Wielokulturowe środowisko historyczne Lwowa w XIX i XX w., t. 3, red. J. Maternicki, L. Zaszkilniak, Rzeszów 2005, s. 46-60

Z. Romek, Wizja dziejów Polski według krakowskiej szkoły historycznej a podręczniki szkolne III RP, w: Krakowska szkoła historyczna a Polskie Towarzystwo Historyczne. Studia historiograficzne, red. P. Biliński, P. Plichta, Kraków 2017, s. 165-182

H. Schnädelbach, Filozofia w Niemczech 1831-1933, tłum. K. Krzemieniowa, Warszawa 1984

H. Słoczyński, Z dziejów czarnej legendy krakowskiej historiografii konserwatywnej. Józef Szujski w opiniach wspótczesnych i potomnych, „Kwartalnik Historyczny” 102, 1995, nr 3/4, s. 209-244

R. Stobiecki, O pewnej wspótczesnej, brawurowej próbie odczytania dziedzictwa krakowskiej szkoły historycznej, w: Krakowska szkoła historyczna a Polskie Towarzystwo Historyczne. Studia historiograficzne, red. P. Biliński, P. Plichta, Kraków 2017, s. 183-191

R. Swakoń, Ideał nauki Józefa Kazimierza Plebańskiego (1831-1897), „Historyka. Studia Metodologiczne" 49, 2019, s. 239-262

R. Swakoń, Wizja świata i człowieka Józefa Kazimierza Plebańskiego (1831-1897), „Historyka. Studia Metodologiczne" 48, 2018, s. 373-393

A. Wardzińska, Dwa spojrzenia na historię Polski. Polemika demokratów lwowskich Henryka Schmitta i Ludwika Wolskiego z przedstawicielem krakowskiej „nowej szkoły historycznej” Józefem Szujskim w latach 70. XIX wieku, „Klio Polska. Studia i Materiały z Dziejów Historiografii Polskiej” 9, 2017, s. 7-31

A. Wierzbicki, Wokót „czarnej legendy” historiografii krakowskich konserwatystów, „Kwartalnik Historyczny" 104, 1997, nr 2, s. 63-87

J. Wnęk, Akademia Umiejętności na kartach „Biblioteki Warszawskiej” w latach 1872-1914, „Rocznik Biblioteki Naukowej PAU i PAN w Krakowie" 52, 2007, s. 355-379

K. Zamorski, Historyzm i narodziny krakowskiej szkoły historycznej, w: Józef Szujski 1835-1883. Materiały $z$ posiedzenia naukowego $w$ dniu 25 listopada 2013 roku, red. W. Lohman, Kraków 2015, s. 51-59

K. Zamorski, Krakowska szkoła historyczna a zagadnienie periodyzacji dziejów, w: Krakowska szkoła historyczna a Polskie Towarzystwo Historyczne. Studia historiograficzne, red. P. Biliński, P. Plichta, Kraków 2017, s. 13-24 


\section{Józef Kazimierz Plebański’s critique of the so-called Kraków school of history}

This article deals with the criticism to which a Warsaw historian, Józef Kazimierz Plebański, subjected works by representatives of the so-called Kraków school of history. Plebański, who studied under Ranke and shared Ranke's historicist outlook, concentrated his criticism on the present-mindedness of the Kraków scholars' interpretation of Polish history, considering it to be the key methodological error they committed. Accusing the Kraków school's representatives of interpreting Polish history from the perspective of their own political ideology, he insisted, in compliance with the fundamental principle of historicism, that the past should be understood on its own terms. Following this perspective, the article shows how Plebański perceived the phenomenon known as the 'new historical school' and how he viewed works by such scholars as J. Szujski, W. Kalinka, M. Bobrzyński and W. Zakrzewski (whom Plebański also included among members of the Kraków school of history). Interestingly, Plebański, as can be assumed, did not regard Smolka as one of the representatives of the school in question, including among them Wincenty Zakrzewski.

Rafał Swakoń - doktorant Wydziału Historycznego Uniwersytetu Jagiellońskiego. Zainteresowania badawcze koncentruje wokół dziejów polskiej historiografii w XIX w. Przygotowuje rozprawę doktorską poświęconą krakowskiemu środowisku historycznemu w drugiej połowie XIX w. E-mail: rafal.swakon@doctoral.uj.edu.pl 